\title{
Gæsteredaktørens forord
}

Der er ved udarbejdelsen af dette temanummer lagt vægt på to forhold. For det første skulle artiklerne bringe nyt stof, nye indsigter og nye perspektiver inden for sociokulturelle studier af seksualitet og samfund. For det andet skulle artiklerne være af relevans for politiske og andre offentlige debatter om dette emne i Danmark her i begyndelsen af 2000-tallet.

Den danske diskussion om seksualitet har gennemløbet en særlig udvikling i de allerseneste år. En række felter er blevet genstand for stor bekymring. Således har man drøftet mulige skadevirkninger af pornografi, af prostitution, og af "seksualiseringen af det offentlige rum"; og der er fremsat krav om kriminalisering af køb af seksuelle ydelser, samt om forbud mod eller begrænsninger i forhold til pornografi og seksualisering. Der er blevet ytret frygt for at der dømmes for få af de mænd som kvinder anklager for voldtægt, og fremsat krav om omvendt bevisbyrde (dvs. at den angivelige gerningsmand selv skal bevise sin uskyld). Pædofili har været genstand for omfattende opmærksomhed i Danmark siden slutningen af 1980'erne, og bekymringen er i de seneste år vokset til panik i omfang og styrke ${ }^{1}$. Også ikke-mindreårige unges frivillige og samtykkende forhold med ældre, og overhovedet unges seksualitet, er genstand for bekymring (herunder deres påklædning, deres færden på internetttet, deres pornoforbrug, deres ønske om at blive model). Seksualitet mellem mennesker med dansk kulturbaggrund og mennesker med ikke-vestlig kulturbaggrund optræder nu i diskussionerne på en særlig og bekymret måde. Sådanne relationer opfattes som et muligt område for danskernes udøvelse af diskrimination, racisme, undertrykkelse og overgreb - således i forbindelse med såkaldt "kvindehandel", eller når danskere har seksuelle relationer med mennesker i ikke-vestlige kulturer, eller ved krav om at man ikke må omtale indvandrermænds andel $i$ antallet af voldtægter. Overhovedet kan det forekomme som om seksualitet i den danske diskussion først og fremmest optræder under bekymringens fortegn. Nydelsens kortvarige æra er forbi, lader det til; nu hersker forestillinger om potentielt allestedsnærværende "misbrug", "krænkelse" og "overgreb".

Denne udvikling kan registreres i medierne og kommer klart til udtryk i den politiske debat. Her er det ikke mindst partierne på det man i gamle dage kaldte venstrefløjen - Socialdemokraterne, SF og Enhedslisten - der er bekym- 
rede, sammen med de Radikale. Krav om begrænsninger eller forbud på seksualitetens område har i stigende grad karakteriseret disse partiers politik siden 2000, ikke blot som udtryk for en række enkelte politikeres aktiviteter, men efterhånden også i partiprogrammer og hovedbestyrelsesbeslutninger. Bekymringen har også ført til en række tiltag, både på det statslige og på det kommunale niveau. Københavns Borgerrepræsentationen har i marts 2006 med Socialdemokratiets, De Radikales og SFs stemmer - vedtaget at henstille pr. brev til samtlige ansatte i kommunen at de ikke køber seksuelle tjenesteydelser. Ligeledes blev det af de samme partier, plus Enhedslisten, besluttet at kommunen ikke skulle have forretningsforbindelser med hoteller der formidler escortservice. Og i februar 2006 har Borgerrepræsentationen - på Socialdemokraternes foranledning og med de samme partiers stemmer - besluttet at medarbejderne ikke længere må hjælpe handicappede med kontakt til prostituerede (til trods for at der i Socialministeriets vejledning på området står det modsatte). Et SF-medlem af borgerrepræsentationen luftede kort efter tanken om at bibliotekspersonalet skulle rive annoncer for sex ud af aviserne. ${ }^{2} \mathrm{SF}$, Socialdemokraterne og Dansk Folkeparti fremsatte i maj 2005 ønske om forbud mod husstandsomdelte reklamer der rummer illustrationer med seksuelle undertoner. SF og Enhedslisten har i marts 2007 fremsat forslag i Folketinget om at medier, der bringer annoncer for købesex, skal mærke disse med advarsler om forbrugets skadevirkninger (herunder organiseret kriminalitet og stofmisbrug). Socialdemokratiet har i april 2007 fremført ønske om forbud mod porno i alle tv-pakker.

Givetvis er der mange samfundsmæssige og kulturelle faktorer der spiller en rolle for denne nye udvikling. Blandt disse kan peges på, at den herskende politiske ideologi blandt de tidligere venstrefløjspartier nu ikke længere synes at koncentrere sig om arbejderes og funktionærers befindende og muligheder i arbejde og fritid. I stedet er trådt en ideologi om at kampen gælder de "undertrykte", "marginaliserede" og "ekskluderede" - herunder ikke mindst kvinder og indvandrere fra ikke-vestlige kulturer. Udbredelsen af feministiske tankebaner generelt i samfundet, og den betydelige andel af akademisk uddannede feminister blandt politikere på "venstrefløjen" og hos de Radikale, spiller naturligvis en væsentlig rolle i denne sammenhæng. Det bør understreges at der, internationalt og i nogen grad i Danmark, findes andre typer af feminisme der ikke har det som et hovedmål at kræve stramninger og forbud i forhold til seksualitetens udfoldelser ${ }^{3}$.

Den bekymrede tilgang til seksualitet har også gjort sig stærkt gældende i akademiske publikationer. Ikke mindst nogle såkaldte "videnscentre" inden for området har spillet og spiller en betydelig rolle her. Sådanne bekymringsorienterede akademiske bestræbelser opfatter uden tvivl ofte sig selv som "kritiske" - de vil jo netop hjælpe angivelige "ofre" og befri dem fra "undertrykkelse", "marginalisering" og "udstødelse". Men der skal mere til end som så for at forskning kan kalde sig kritisk. For at illustrere med et egentlig banalt 
eksempel: Hvis en bekymret repræsentant for et undersøgelsesforetagende i statsregi i første halvdel af det 20. århundrede spurgte en "homoseksuel" om homoseksualitetens elendigheder, havde undersøgeren en god chance for at producere de bekymrede og bekymrende svar, som hun eller han på forhånd forventede og ønskede. En tilsvarende bekymringsproblematik gør sig gældende ved nutidige undersøgelser blandt prostituerede, og det bør en forsker være klar over og tage højde for, hvis ellers hendes/hans undersøgelse skal gå for at være kritisk, eller med et andet ord: videnskabelig.

Bekymrethedsorienteringen har således en tendens til at producere de resultater, som dens synsfelt og tilgang på forhånd har lagt op til. Det er derfor på tide at der fremlægges forskningsresultater, der ikke har taget bekymringen som deres væsentligste og indiskutable præmis, men som er i stand til kritisk at afdække begrænsningerne i bekymringshorisontens ideologiske forudsætninger og praktiske konsekvenser, samt til at fremlægge nyt stof og pege mod andre perspektiver.

Der er mere end nogensinde i de sidste 40 år brug for kritisk forskning $\mathrm{i}$ emneområdet seksualitet og samfund. Det er ulykkeligt, hvis offentligheden overvejende må tage til takke med oplysninger fra ensidig eller urigtig "forskning". Og det er ulykkeligt, hvis ministerier og andre myndigheder er henvist til at træffe beslutninger på baggrund af råd og materiale, der er indhentet fra ensidig eller urigtig forskning. Det er vigtigt at sikre udfoldelsesmuligheder, og dermed institutionelle rammer, for kritisk, nuanceret og ucensureret forskning i emnet seksualitet og samfund.

Henning Bech

\section{Noter}

1. Jf. Henning Bech: Kvinder og mænd. København: Hans Reitzels Forlag, 2005, s.201-247.

2. Jeg takker stud.scient.soc. Morten Wöldike Olsen for denne og den følgende henvisning.

3. Jf. Henning Bech, oa.a., s. 53-69; 150-163. 